Stawomir Chrost*

Kielce

\title{
Stosunek młodzieży gimnazjalnej do wybranych norm moralnych zawartych w Dekalogu
}

Kwestie aksjologiczne i normatywne znajdują się obecnie w centrum zainteresowań przedstawicieli różnych gałęzi nauki, także pedagogów czy socjologów. Wychowanie do wartości, a właściwie do realnego życia nimi w relacjach do drugiej osoby i całego świata, jest częścią integralnego wychowania człowieka i staje się przede wszystkim domeną wychowania religijnego. $\mathrm{W}$ procesie tym $\mathrm{w}$ realiach polskich nadrzędną rolę mogą odegrać wartości i nakazy moralne zawarte w Dekalogu, który w chrześcijaństwie reguluje kwestie miłości człowieka do Boga i drugiego człowieka.

Dekalog (gr. 'dziesięć słów', 'dziesięć przykazań Bożych') - według Małego Słownika Teologicznego - to klasyczne określenie nadanych ludowi Starego Przymierza nakazów i zakazów, które, ujęte w dziesięć zdań (Wj 20, 2-17; Pwt 5, 6-21), z jednej strony porządkują pod względem społecznym i etycznym życie tegoż ludu, a z drugiej mają mu - jako monoteistycznej wspólnocie kultowej zrodzonej mocą zawartego przymierza - zapewnić

* Ks. dr hab. Sławomir Chrost, prof. UJK, jest kierownikiem Zakładu Pracy Socjalnej i Integracji Społecznej w Instytucie Pedagogiki i Psychologii Uniwersytetu Jana Kochanowskiego w Kielcach. Adres: Instytut Pedagogiki i Psychologii UJK, ul. Krakowska 11, 25-029 Kielce; e-mail: schrost@op.pl. 
trwałą egzystencję pośród politeistycznego otoczeniaํ. Katechizm Kościoła katolickiego podkreśla, że autorem Dekalogu jest sam Bóg: „Dziesięć przykazań, będąc wyrazem podstawowych powinności człowieka względem Boga i względem bliźniego, objawia w swojej istotnej treści poważne zobowiązania. Są one ze swojej natury niezmienne i obowiązują zawsze i wszędzie. Nikt nie może od nich dyspensować. Dziesięć przykazań wyrył Bóg w sercu człowieka"2. Jacek Salij, snując refleksję nad Dekalogiem, wskazuje na istotowe powiązanie dziesięciu przykazań z moralnością:

Jak się mają przykazania Boże do tego prawa moralnego, które nosimy w sobie z racji, że jesteśmy ludźmi? Otóż przykazania są darem, jakiego Bóg udzielił grzesznemu człowiekowi, kiedy go postanowił szukać jako Zbawca. Wśród różnych środków, za pomocą których Bóg postanowił ocalić człowieka, znajdują się również Jego przykazania. Za pomocą przykazań Bóg Zbawca chce nam pomóc rozpoznać prawidłowo to prawo, które nosimy w sobie jako Jego stworzenia. [...] Przykazania Boże ułatwiają nam prawidłowe odczytanie tego prawa moralnego, które nosimy w naszych sumieniach. [...] Boże przykazania spełniają poniekąd rolę promieni podczerwonych, dzięki którym możemy bezbłędnie i z całą pewnością odczytać „tekst” zapisany w naszych sumieniach również te partie „tekstu”, które nasz tzw. „zdrowy rozsądek” miałby ochotę odczytać niepoprawnie ${ }^{3}$.

Problem, który stał się motywem podjęcia badań, wyraża się w pytaniu: jaki jest stosunek młodzieży gimnazjalnej do norm moralnych zawartych w Dekalogu? Wydaje się, że młodzież gimnazjalna jako grupa fokusowa jest grupa, w której najlepiej widać przemiany dokonujące się w życiu społeczno-obyczajowym społeczeństwa, w tym zmiany dokonujące się w edukacji młodzieży także w wymiarze wychowania religijnego. Celem artykułu jest próba empirycznej ilustracji rzeczywistości życia młodzieży gimnazjalnej, wyciąnnięcie wniosków dotyczących diagnozy i prognozy badanej sytuacji społeczno-kulturowej oraz sformułowanie postulatów wychowawczych.

${ }^{1}$ Hasło: „Dekalog”, w: Mały Stownik Teologiczny, red. Karl Rahner, Herbert Vorgrimler, thum. Tadeusz Mieszkowski, Paweł Pachciarek (Warszawa: Instytut Wydawniczy PAX, 1996), 92.

${ }^{2}$ Katechizm Kościoła katolickiego, nr 2072 (Poznań: Pallottinum, 1984), 477.

3 Jacek Salij, Dekalog (Poznań: Księgarnia Św. Wojciecha, 1990), 7-9. 


\section{Moralność i religia}

Jeśli, idąc za Encyklopedia Katolicka, uznamy, że religia jest realnym związkiem człowieka z Bogiem, to stwierdzenie to implikuje podmiot i przedmiot religii.

Podmiot - jest nim człowiek jako istota rozumna i wolna, świadoma swej egzystencji, wielkości, godności, oryginalności wobec świata kosmicznego, biologicznego i zwierzęcego, a także niewystarczalności, ułomności, ograniczoności w bycie i istnieniu [...]. Przedmiot - głównym przedmiotem religii specyfikowanym przez transcendencję jest Bóg; człowiek w aktach religijnych odnosi się do rzeczywistości pozaświatowej, boskiej, która transcenduje wszystko to, co istnieje poza nią, i nie może być sprowadzona do innego bytu. [...] przedmiot wiary religijnej jest definiowany nie tylko w kategorii bytu, ale i wartości jako ostatecznego celu dążeń człowieka, finalnego spełnienia i zaspokojenia wszystkich jego pragnień i oczekiwań; Święte jako przedmiot religii zawiera w sobie wszystkie największe wartości: prawdę, dobro, piękno, miłość, pełnię wszelkich doskonałości, szczęście, życie, istnienie nieprzemijające, wieczne i nieutracane; jawi się jako absolutna wartość 4 .

Cyprian Rogowski przypomina o związku religii z religijnością:

Ujmując religijność z perspektywy pedagogicznoreligijnej i teologicznej, pojęcie to oznacza wrażliwość, która pozwala człowiekowi otworzyć się na religijny wymiar rzeczywistości. Patrząc od strony teologicznej, wrażliwość religijna konkretyzuje odniesienie człowieka do Transcendencji. Stąd też jest ona również podstawą każdej relacji, jaka zachodzi między człowiekiem wierzącym a Bogiem, a także każdej religijnej dynamiki w ogóle 5 .

Religijność - współcześnie - można i należy interpretować szeroko. Różnymi wymiarami religijności są: wrażliwość, postawa, treść, komunikacja, horyzont religijnej motywacji ${ }^{6}$.

${ }^{4}$ Marian Rusecki, „Religia IV: aspekt teologiczny”, w: Encyklopedia Katolicka, t. XVI, red. Edward Gigilewicz i in. (Lublin: TN KUL, 2012), 1408.

${ }^{5}$ Cyprian Rogowski, Pedagogika religii (Toruń: Wydawnictwo Adam Marszałek, 2011), 113.

${ }^{6}$ Por. tamże, 114. 
Człowiek żyje „między sacrum i profanum”. Znamieniem współczesności jest kryzys człowieczeństwa, wyrażony przy pomocy pojęcia „błąd antropologiczny". Ów błąd w definiowaniu i pojmowaniu człowieka jest natomiast konsekwencją kryzysu humanizmu, który oznacza przede wszystkim oderwanie rzeczywistości ludzkiego życia i samego człowieka od Transcendencji i zredukowania go wyłącznie do wymiarów doczesności. Dostrzega się zatem tylko pewne aspekty człowieczeństwa, negując pozostałe: sferę nadprzyrodzoności i odniesienie metafizyczne. Nie stawia się pytania o pozaziemski sens życia i powołania człowieka. Poprzestaje się na ujmowaniu go z pozycji konsumenta, który ma się realizować głównie w sferze cielesnozmysłowej - czemu podporządkowane zostają jego umysł i psychika w procesie kształcenia oraz wychowania. Oznacza to, że w procesie tym i całym systemie wychowania - a w konsekwencji w organizowaniu kształtu życia społecznego - brakuje integralnego spojrzenia na człowieka w swej istocie będącego osobą, z wszystkimi jej wymiarami i przysługującymi prawami.

Społeczne życie człowieka regulowane jest przez cztery podstawowe sfery rzeczywistości: moralna, religijna, prawną i zwyczajową. W ich ramach człowiek podejmuje działalność opartą na zespołach reguł określających bezkonfliktowe społecznie funkcjonowanie właściwe zarówno z indywidualnego, jak i instytucjonalnego punktu widzenia. Zasygnalizowane sfery wiążą się z czterema głównymi systemami wartości, ukierunkowującymi aktywność życiową jednostki. Ich społeczny charakter oznacza, że są dla jednostki faktem zastanym, a zatem ich obowiązywanie może być określone jako imperatyw.

Według Haliny Mielickiej wartości moralne odnoszą swoje istnienie do cech osobowości ludzi i osądów ich postępowania. Związane są one z normami określającymi pożądane społeczne cele i kategoryzują zachowania człowieka z perspektywy dobra i zła społecznego. Wartości moralne pojawiają się zwykle wówczas, gdy postępowanie ludzi uznawane jest za sprawiedliwe lub niesprawiedliwe, krzywdzące lub biorące pod uwagę godność innych. Wartości religijne są natomiast związane z dogmatami, których sankcje odnoszą się do pojęcia błogosławieństwa i grzechu oraz życia doczesnego i pośmiertnego ${ }^{7}$.

${ }^{7}$ Por. Halina Mielicka, „Wartości ekonomiczne a systemy normatywne”, w: Badania Naukowe, z. 5, red. Bożydar J. L. Kaczmarek (Kielce: Wyższa Szkoła Ubezpieczeń Społecznych, 2001), 126. 
Powiązania między religią i moralnością są różnorakie. Janusz Mariański wymienia pięć postaci zależności między dogmatyczną treścią katolicyzmu a moralnością:

a) zależność genetyczna - istota czczona w danej religii jest równocześnie kodyfikatorem norm moralnych;

b) zależność logiczna - dyrektywy moralne wynikają z dogmatów wiary na zasadzie wyłączności;

c) zależność psychologiczna - wiedza o dobru i złu zrosła się psychologicznie z określonymi, przekazywanymi od dzieciństwa, treściami dogmatycznymi;

d) treść wierzeń religijnych określa oceny i normy;

e) możliwy jest związek między religijnością a poziomem moralnym ${ }^{8}$.

Maria Ossowska przedstawiła religię (katolicyzm) jako dostarczycielkę hamulców w moralności z jednej strony, i jako dostarczycielkę impulsów pozytywnych z drugiej'.

Sławomir H. Zaręba wskazuje na czynniki odpowiedzialne za kryzys w socjalizacji religijnej młodego pokolenia. Są to:

a) transformacja społeczno-kulturowa współczesnych społeczeństw;

b) spadek dynamiki religijności dzieci;

c) rozluźnienie więzi młodego pokolenia z parafia;

d) tendencja do samostanowienia norm moralnych;

e) przerzucanie odpowiedzialności za wychowanie religijne $\mathrm{z}$ rodzin na Kościół;

f) wpływ kultury masowej;

g) spadek siły oddziaływania instytucji dotychczas odpowiedzialnych za socjalizację religijną ${ }^{10}$.

Stosunek do moralnych zasad katolicyzmu socjologowie uważają za jeden ze wskaźników postawy wobec religii. „Kierunek przemian w moralności socjologowie postrzegają jako powolne odchodzenie od moralności bezwarunkowego zakazu do moralności indywidualnego osądu. Kryterium oceny jest redukowane do sytuacyjnej korzyści i indywidualnej użyteczności. W sensie przenośnym słowo dekalog oznacza zbiór podstawowych dy-

${ }^{8}$ Por. Janusz Mariański, „Moralność a religia”, w: Leksykon socjologii religii, red. Maria Libiszowska-Żółtkowska, Janusz Mariański (Warszawa: Verbinum, 2004), 249-250.

9 Por. Maria Ossowska, „Czy moralność zależy od religii?”, Nowa Szkoła 6 (1958): 2-6.

${ }^{10}$ Por. Sławomir Zaręba, „Socjalizacja religijna”, w: Leksykon socjologii religii, red. Maria Libiszowska-Żółtkowska, Janusz Mariański (Warszawa: Verbinum, 2004), 370-374. 
rektyw postępowania w jakiejś dziedzinie"'11. Według raportu CBOS od 2005 roku systematycznie przybywa Polaków, którzy posiadanie jednoznacznych zasad moralnych uznają za pożądane, lecz dopuszczają iż w pewnych sytuacjach zasady te można uznać za nieobowiązujące. Większość badanych (57\%) sądzi, że rozstrzyganie o dobru i złu powinno być przede wszystkim wewnętrzną sprawą każdego człowieka. Jeżeli chodzi o opinie na temat związków między religią a moralnością, prawie 3/4 Polaków uważa, że religia nie musi uzasadniać słusznych nakazów moralnych. Przekonanie, iż wyłącznie religia może stanowić podstawę właściwej moralności, wyraża jedynie co szósty ankietowany ${ }^{12}$.

\section{Badania}

Badania dotyczące stosunku młodzieży do wybranych norm religijnych zawartych w Dekalogu zostały przeprowadzone metodą sondażu diagnostycznego w styczniu 2014 roku, w jednym z pięciu państwowych gimnazjów funkcjonujących na terenie 70-tysięcznego miasta w województwie świętokrzyskim. Próbę 100 gimnazjalistów wybrano losowo. W badaniu wzięło udział 40 uczniów i 60 uczennic. Do każdego przykazania Dekalogu (numeracja rzymska) zostały przedstawione dwie sytuacje życiowe (numeracja arabska; numery odpowiadają pytaniom w ankiecie) korelujące z mentalnością młodych ludzi ${ }^{13}$.

I. Nie będziesz miał cudzych bogów przede Mną.

4. Podejmowanie decyzji odnośnie własnej przyszłości w oparciu o horoskopy jest grzechem.

5. Powieszenie we własnym pokoju plakatu swojego idola (piosenkarza, aktora, piłkarza itp.) zamiast krzyża nie jest czymś złym.

II. Nie będziesz brał imienia Pana Boga twego nadaremno.

6. Przyjęcie Komunii św. przez rodziców mieszkających wspólnie bez ślubu kościelnego jest dopuszczalne z okazji chrztu ich dziecka.

${ }^{11}$ Maria Libiszowska-Żółtkowska, „Dekalog”, w: Leksykon socjologii religii, red. Maria Libiszowska-Żółtkowska, Janusz Mariański (Warszawa: Verbinum, 2004), 431.

12 Religijność a zasady moralne (Warszawa: CBOS, 2014).

${ }^{13}$ Autor zdaje sobie sprawę, że czytający tekst może mieć wątpliwości natury etycznej co do sformułowań użytych w badaniu. Należy jednak zauważyć, że wszelkie kwestie zgod- 
7. Zniszczenie Pisma św. przez artystę na scenie jako wyraz wolności artystycznej jest dopuszczalne.

III. Pamiętaj, abyś dzień święty święcił.

8. Deszczowa pogoda jest wystarczającym powodem, by nieobecność na Mszy św. niedzielnej uznać za usprawiedliwioną.

9. Uczestniczenie we Mszy św. w każdą niedzielę jest obowiązkowe tylko w czasie przygotowań do I Komunii św. i bierzmowania, poza tym okresem jest tylko zalecane.

IV. Czcij ojca swego i matkę swoją.

10. Aroganckie odnoszenie się do rodziców jest usprawiedliwione, jeśli nie akceptuje się ich poglądów.

11. Odmówienie pomocy rodzicom jest dopuszczalne ze względu na chęć realizacji w tym czasie własnego hobby.

V. Nie zabijaj.

12. Palenie papierosów jest grzechem.

13. Chęć ulżenia cierpieniom jest wystarczającym powodem do skrócenia życia ciężko choremu człowiekowi.

VI. Nie cudzołóż.

14. Współżycie seksualne przed ślubem jest dozwolone, jeśli narzeczeni uważają że się kochają.

15. Masturbacja nie jest czymś złym, bo jest to normalny etap rozwoju w życiu seksualnym człowieka.

VII. Nie kradnij.

16. Jeśli przypuszcza się, że rodzice mogą nie dać pieniędzy na kosmetyki lub na doładowanie telefonu komórkowego, można je wziąć (zabrać) z portfela rodziców po kryjomu.

17. Pracę domową przepisaną z cudzego opracowania zamieszczonego w Internecie można oddać nauczycielowi jako własną, jeśli na samodzielne napisanie zabrakło czasu.

VIII. Nie mów fałszywego świadectwa przeciw bliźniemu swemu.

18. Okłamywanie rodziców lub nauczycieli w celu uniknięcia kary jest dopuszczalne.

19. Umieszczenie w Internecie dla zabawy filmu stawiającego koleżankę lub kolegę w złym świetle jest dopuszczalne.

ności lub rozbieżności z doktryną katolicką zostały uczniom po przeprowadzonych badaniach obszernie wyjaśnione. 
IX. Nie pożąajaj żony bliźniego twego.

20. Oglądanie czasopism erotycznych nie jest czymś złym, bo pomaga rozładować napięcie seksualne.

21. Występowanie w reklamach bardzo skąpo ubranych (roznegliżowanych) dziewcząt jest dopuszczalne, bo może przyczynić się do wzrostu sprzedaży reklamowanego produktu.

X. Ani żadnej rzeczy, która jego jest.

22. Dobieranie sobie przyjaciół ze względu na to, że są bogaci, nie jest czymś złym.

23. Wizyta u babci (dziadka) ze względu na spodziewane kieszonkowe z jej (jego) ostatniej emerytury nie jest czymś złym.

Poniżej przedstawione są tabele zbiorcze wyników badań. Pierwsza tabela przedstawia deklarowany (teoretyczny) stosunek młodzieży do norm moralnych zawartych w Dekalogu. Respondenci zostali bowiem poinformowani, że ankieta dotyczy norm moralnych mających swoje źródło w Dekalogu. Na wstępie badania mieli więc za zadanie określenie swojego stosunku do katechizmowych sformułowań dziesięciu Bożych przykazań.

Druga tabela prezentuje stosunek młodzieży wobec postaw życiowych stanowiących rozwinięcie norm moralnych na bazie dziesięciu Bożych przykazań. Jest to więc stosunek wyrażający bardziej praktyczny wymiar - realizowanie w codziennym życiu norm objawionych przez Boga.

Tab. 1. Deklarowany stosunek młodzieży do Dziesięciu Bożych Przykazań

\begin{tabular}{|c|l|l|l|l|l|l|}
\hline $\begin{array}{c}\text { Przy- } \\
\text { kaza- } \\
\text { nie }\end{array}$ & $\begin{array}{l}\text { Zdecydowa- } \\
\text { nie się zga- } \\
\text { dzam (5) }\end{array}$ & $\begin{array}{l}\text { Raczej się } \\
\text { zgadzam } \\
(4)\end{array}$ & $\begin{array}{l}\text { Trudno } \\
\text { powie- } \\
\text { dzieć (3) }\end{array}$ & $\begin{array}{l}\text { Raczej się } \\
\text { nie zgadzam } \\
(2)\end{array}$ & $\begin{array}{l}\text { Zdecydowa- } \\
\text { nie się nie } \\
\text { zgadzam (1) }\end{array}$ & Średnia \\
\hline I & $\mathrm{K}-32=$ & $\mathrm{K}-13=$ & $\mathrm{K}-9=$ & $\mathrm{K}-4=$ & $\mathrm{K}-2=$ & 4,35 \\
& $53,3 \%$ & $21,6 \%$ & $15 \%$ & $6,6 \%$ & $3,3 \%$ & \\
& $\mathrm{M}-31=$ & $\mathrm{M}-6=$ & $\mathrm{M}-2=$ & $\mathrm{M}-0$ & $\mathrm{M}-1=$ & \\
& $77,5 \%$ & $15 \%$ & $5 \%$ & $\mathrm{R}=4$ & $2,5 \%$ & \\
& $\mathrm{R}=63$ & $\mathrm{R}=19$ & $\mathrm{R}=11$ & & $\mathrm{R}=3$ & \\
\hline II & $\mathrm{K}-16=$ & $\mathrm{K}-20=$ & $\mathrm{K}-17=$ & $\mathrm{K}-3=$ & $\mathrm{K}-4=$ & 3,83 \\
& $26,6 \%$ & $33,3 \%$ & $28,3 \%$ & $5 \%$ & $6,6 \%$ & \\
& $\mathrm{M}-19=$ & $\mathrm{M}-9=$ & $\mathrm{M}-9=$ & $\mathrm{M}-1=$ & $\mathrm{M}-2=$ & \\
& $47,5 \%$ & $22,5 \%$ & $22,5 \%$ & $2,5 \%$ & $5 \%$ & \\
& $\mathrm{R}=35$ & $\mathrm{R}=29$ & $\mathrm{R}=26$ & $\mathrm{R}=4$ & $\mathrm{R}=6$ & \\
\hline
\end{tabular}


Tab. 1. Deklarowany stosunek młodzieży (cd.)

\begin{tabular}{|c|c|c|c|c|c|c|}
\hline $\begin{array}{l}\text { Przy- } \\
\text { kaza- } \\
\text { nie }\end{array}$ & $\begin{array}{l}\text { Zdecydowa- } \\
\text { nie się zga- } \\
\text { dzam (5) }\end{array}$ & $\begin{array}{l}\text { Raczej się } \\
\text { zgadzam } \\
(4)\end{array}$ & $\begin{array}{l}\text { Trudno } \\
\text { powie- } \\
\text { dzieć (3) }\end{array}$ & $\begin{array}{l}\text { Raczej się } \\
\text { nie zgadzam } \\
\text { (2) }\end{array}$ & $\begin{array}{l}\text { Zdecydowa- } \\
\text { nie się nie } \\
\text { zgadzam (1) }\end{array}$ & Średnia \\
\hline III & $\begin{array}{l}K-29= \\
48,3 \% \\
M-27= \\
67,5 \% \\
R=56\end{array}$ & $\begin{array}{l}\mathrm{K}-16= \\
26,6 \% \\
M-8= \\
20 \% \\
\mathrm{R}=24\end{array}$ & $\begin{array}{l}\mathrm{K}-12= \\
20 \% \\
\mathrm{M}-2= \\
5 \% \\
\mathrm{R}=14\end{array}$ & $\begin{array}{l}\mathrm{K}-2= \\
3,3 \% \\
\mathrm{M}-2 \\
=5 \% \\
\mathrm{R}=4\end{array}$ & $\begin{array}{l}\mathrm{K}-1= \\
1,6 \% \\
\mathrm{M}-1= \\
2,5 \% \\
\mathrm{R}=2\end{array}$ & 4,28 \\
\hline IV & $\begin{array}{l}K-55= \\
91,6 \% \\
M-35= \\
87,5 \% \\
R=90\end{array}$ & $\begin{array}{l}\mathrm{K}-3= \\
5 \% \\
\mathrm{M}-4= \\
10 \% \\
\mathrm{R}=7\end{array}$ & $\begin{array}{l}\mathrm{K}-0 \\
\mathrm{M}-1= \\
2,5 \% \\
\mathrm{R}=1\end{array}$ & $\begin{array}{l}\mathrm{K}-1= \\
1,6 \% \\
\mathrm{M}-0 \\
\mathrm{R}=1\end{array}$ & $\begin{array}{l}\mathrm{K}-1= \\
1,6 \% \\
\mathrm{M}-0 \\
\mathrm{R}=1\end{array}$ & 4,84 \\
\hline $\mathrm{V}$ & $\begin{array}{l}\mathrm{K}-56= \\
93,3 \% \\
M-33= \\
82,5 \% \\
\mathrm{R}=89\end{array}$ & $\begin{array}{l}\mathrm{K}-3= \\
5 \% \\
\mathrm{M}-2= \\
5 \% \\
\mathrm{R}=5\end{array}$ & $\begin{array}{l}\mathrm{K}-0 \\
\mathrm{M}-5= \\
12,5 \% \\
\mathrm{R}=5\end{array}$ & $\begin{array}{l}\mathrm{K}-0 \\
\mathrm{M}-0 \\
\mathrm{R}=0\end{array}$ & $\begin{array}{l}\mathrm{K}-1= \\
1,6 \% \\
\mathrm{M}-0 \\
\mathrm{R}=1\end{array}$ & 4,77 \\
\hline VI & $\begin{array}{l}\mathrm{K}-39= \\
65 \% \\
M-26= \\
65 \% \\
R=65\end{array}$ & $\begin{array}{l}\mathrm{K}-4= \\
6,6 \% \\
M-8= \\
20 \% \\
\mathrm{R}=12\end{array}$ & $\begin{array}{l}\mathrm{K}-10= \\
16,6 \% \\
M-5= \\
12,5 \% \\
R=15\end{array}$ & $\begin{array}{l}\mathrm{K}-1= \\
1,6 \% \\
\mathrm{M}-1= \\
2,5 \% \\
\mathrm{R}=2\end{array}$ & $\begin{array}{l}K-6= \\
10 \% \\
M-0 \\
R=6\end{array}$ & 4,28 \\
\hline VII & $\begin{array}{l}\mathrm{K}-54= \\
90 \% \\
M-29= \\
72,5 \% \\
\mathrm{R}=83\end{array}$ & $\begin{array}{l}\mathrm{K}-4= \\
6,6 \% \\
\mathrm{M}-7= \\
17,5 \% \\
\mathrm{R}=11\end{array}$ & $\begin{array}{l}K-0 \\
M-4= \\
10 \% \\
R=4\end{array}$ & $\begin{array}{l}\mathrm{K}-0 \\
\mathrm{M}-0 \\
\mathrm{R}=0\end{array}$ & $\begin{array}{l}\mathrm{K}-2= \\
3,3 \% \\
\mathrm{M}-0 \\
\mathrm{R}=2\end{array}$ & 4,73 \\
\hline VIII & $\begin{array}{l}\mathrm{K}-31= \\
51,6 \% \\
\mathrm{M}-23= \\
57,5 \% \\
\mathrm{R}=54\end{array}$ & $\begin{array}{l}\mathrm{K}-22= \\
36,6 \% \\
M-10= \\
25 \% \\
\mathrm{R}=32\end{array}$ & $\begin{array}{l}K-6= \\
10 \% \\
M-6= \\
15 \% \\
R=12\end{array}$ & $\begin{array}{l}\mathrm{K}-0 \\
\mathrm{M}-1= \\
2,5 \% \\
\mathrm{R}=1\end{array}$ & $\begin{array}{l}\mathrm{K}-1= \\
1,6 \% \\
\mathrm{M}-0 \\
\mathrm{R}=1\end{array}$ & 4,37 \\
\hline IX & $\begin{array}{l}K-38= \\
63,3 \% \\
M-25= \\
62,5 \% \\
R=63\end{array}$ & $\begin{array}{l}\mathrm{K}-11= \\
18,3 \% \\
\mathrm{M}-11= \\
27,5 \% \\
\mathrm{R}=22\end{array}$ & $\begin{array}{l}\mathrm{K}-8= \\
13,3 \% \\
\mathrm{M}-3= \\
7,5 \% \\
\mathrm{R}=11\end{array}$ & $\begin{array}{l}K-1= \\
1,6 \% \\
M-0 \\
R=1\end{array}$ & $\begin{array}{l}\mathrm{K}-2= \\
3,3 \% \\
\mathrm{M}-1= \\
2,5 \% \\
\mathrm{R}=3\end{array}$ & 4,41 \\
\hline
\end{tabular}


Tab. 1. Deklarowany stosunek młodzieży (cd.)

\begin{tabular}{|c|l|l|l|l|l|l|}
\hline $\begin{array}{c}\text { Przy- } \\
\text { kaza- } \\
\text { nie }\end{array}$ & $\begin{array}{l}\text { Zdecydowa- } \\
\text { nie się zga- } \\
\text { dzam (5) }\end{array}$ & $\begin{array}{l}\text { Raczej się } \\
\text { zgadzam } \\
(4)\end{array}$ & $\begin{array}{l}\text { Trudno } \\
\text { powie- } \\
\text { dzieć (3) }\end{array}$ & $\begin{array}{l}\text { Raczej się } \\
\text { nie zgadzam } \\
(2)\end{array}$ & $\begin{array}{l}\text { Zdecydowa- } \\
\text { nie się nie } \\
\text { zgadzam (1) }\end{array}$ & Srednia \\
\hline $\mathrm{X}$ & $\mathrm{K}-37=$ & $\mathrm{K}-17=$ & $\mathrm{K}-4=$ & $\mathrm{K}-1=$ & $\mathrm{K}-1=$ & 4,54 \\
& $61,6 \%$ & $28,3 \%$ & $6,6 \%$ & $1,6 \%$ & $1,6 \%$ & \\
& $\mathrm{M}-28=$ & $\mathrm{M}-10=$ & $\mathrm{M}-2=$ & $\mathrm{M}-0$ & $\mathrm{M}-0$ & \\
& $70 \%$ & $25 \%$ & $5 \%$ & $\mathrm{R}=1$ & $\mathrm{R}=1$ & \\
& $\mathrm{R}=65$ & $\mathrm{R}=27$ & $\mathrm{R}=6$ & & & \\
\hline
\end{tabular}

* $\mathrm{K}$ - uczennice, $\mathrm{M}$ - uczniowie

Źródło: opracowanie własne.

Tab. 2. Stosunek młodzieży do wybranych norm moralnych zawartych w Dekalogu

\begin{tabular}{|c|c|c|c|c|c|c|}
\hline $\begin{array}{l}\text { Pytanie/ } \\
\text { Przyka- } \\
\text { zanie }\end{array}$ & $\begin{array}{l}\text { Zdecydo- } \\
\text { wanie się } \\
\text { zgadzam }\end{array}$ & $\begin{array}{l}\text { Raczej się } \\
\text { zgadzam }\end{array}$ & $\begin{array}{l}\text { Trudno } \\
\text { powie- } \\
\text { dzieć }\end{array}$ & $\begin{array}{l}\text { Raczej się } \\
\text { nie zga- } \\
\text { dzam }\end{array}$ & $\begin{array}{l}\text { Zdecydowa- } \\
\text { nie się nie } \\
\text { zgadzam }\end{array}$ & Średnia \\
\hline 4 (I) & $\begin{array}{l}\mathrm{K}-12= \\
20 \% \\
M-5= \\
12,5 \% \\
\mathrm{R}=17\end{array}$ & $\begin{array}{l}\mathrm{K}-15= \\
25 \% \\
M-5= \\
12,5 \% \\
\mathrm{R}=20\end{array}$ & $\begin{array}{l}\mathrm{K}-15= \\
25 \% \\
M-15= \\
37,5 \% \\
\mathrm{R}=30\end{array}$ & $\begin{array}{l}\mathrm{K}-10= \\
16,6 \% \\
M-5= \\
12,5 \% \\
\mathrm{R}=15\end{array}$ & $\begin{array}{l}\mathrm{K}-8= \\
13,3 \% \\
M-10= \\
25 \% \\
\mathrm{R}=18\end{array}$ & 2,88 \\
\hline 5 (I) & $\begin{array}{l}\mathrm{K}-31= \\
51,6 \% \\
\mathrm{M}-17= \\
42,5 \% \\
\mathrm{R}=48\end{array}$ & $\begin{array}{l}\mathrm{K}-15= \\
25 \% \\
\mathrm{M}-7= \\
17,5 \% \\
\mathrm{R}=22\end{array}$ & $\begin{array}{l}\mathrm{K}-5= \\
8,3 \% \\
\mathrm{M}-11= \\
27,5 \% \\
\mathrm{R}=16\end{array}$ & $\begin{array}{l}K-4= \\
6,6 \% \\
M-4= \\
10 \% \\
R=8\end{array}$ & $\begin{array}{l}\mathrm{K}-5= \\
8,3 \% \\
\mathrm{M}-1= \\
2,5 \% \\
\mathrm{R}=6\end{array}$ & 2,02 \\
\hline 6 (II) & $\begin{array}{l}\mathrm{K}-15= \\
25 \% \\
M-11= \\
27,5 \% \\
\mathrm{R}=26\end{array}$ & $\begin{array}{l}K-18= \\
30 \% \\
M-6= \\
15 \% \\
R=24\end{array}$ & $\begin{array}{l}\mathrm{K}-17= \\
28,3 \% \\
\mathrm{M}-15= \\
37,5 \% \\
\mathrm{R}=32\end{array}$ & $\begin{array}{l}K-4= \\
6,6 \% \\
M-6= \\
15 \% \\
R=10\end{array}$ & $\begin{array}{l}K-6= \\
10 \% \\
M-2= \\
5 \% \\
R=8\end{array}$ & 2,20 \\
\hline 7 (II) & $\begin{array}{l}\mathrm{K}-4= \\
6,6 \% \\
\mathrm{M}-1= \\
2,5 \% \\
\mathrm{R}=5\end{array}$ & $\begin{array}{l}\mathrm{K}-6= \\
10 \% \\
M-5= \\
12,5 \% \\
\mathrm{R}=11\end{array}$ & $\begin{array}{l}K-9= \\
15 \% \\
M-4= \\
10 \% \\
R=13\end{array}$ & $\begin{array}{l}\mathrm{K}-16= \\
26,6 \% \\
M-6= \\
15 \% \\
\mathrm{R}=22\end{array}$ & $\begin{array}{l}\mathrm{K}-25= \\
41,6 \% \\
M-24= \\
60 \% \\
\mathrm{R}=49\end{array}$ & 3,99 \\
\hline
\end{tabular}


Tab. 2. Stosunek młodzieży do wybranych norm moralnych (cd.)

\begin{tabular}{|c|c|c|c|c|c|c|}
\hline $\begin{array}{l}\text { Pytanie/ } \\
\text { Przyka- } \\
\text { zanie }\end{array}$ & $\begin{array}{l}\text { Zdecydo- } \\
\text { wanie się } \\
\text { zgadzam }\end{array}$ & $\begin{array}{l}\text { Raczej się } \\
\text { zgadzam }\end{array}$ & $\begin{array}{l}\text { Trudno } \\
\text { powie- } \\
\text { dzieć }\end{array}$ & $\begin{array}{l}\text { Raczej się } \\
\text { nie zga- } \\
\text { dzam }\end{array}$ & $\begin{array}{l}\text { Zdecydowa- } \\
\text { nie się nie } \\
\text { zgadzam }\end{array}$ & Średnia \\
\hline 8 (III) & $\begin{array}{l}\mathrm{K}-8= \\
13,3 \% \\
M-5= \\
12,5 \% \\
\mathrm{R}=13\end{array}$ & $\begin{array}{l}\mathrm{K}-8= \\
13,3 \% \\
M-3= \\
7,5 \% \\
\mathrm{R}=11\end{array}$ & $\begin{array}{l}\mathrm{K}-12= \\
20 \% \\
\mathrm{M}-11= \\
27,5 \% \\
\mathrm{R}=23\end{array}$ & $\begin{array}{l}\mathrm{K}-13= \\
21,6 \% \\
\mathrm{M}-7= \\
17,5 \% \\
\mathrm{R}=20\end{array}$ & $\begin{array}{l}K-19= \\
31,6 \% \\
M-14= \\
35 \% \\
R=33\end{array}$ & 3,71 \\
\hline 9 (III) & $\begin{array}{l}\mathrm{K}-7= \\
11,6 \% \\
\mathrm{M}-5 \\
=12,5 \% \\
\mathrm{R}=12\end{array}$ & $\begin{array}{l}\mathrm{K}-9= \\
15 \% \\
M-7= \\
17,5 \% \\
\mathrm{R}=16\end{array}$ & $\begin{array}{l}K-9= \\
15 \% \\
M-7= \\
17,5 \% \\
R=16\end{array}$ & $\begin{array}{l}\mathrm{K}-14= \\
23,3 \% \\
\mathrm{M}-7= \\
17,5 \% \\
\mathrm{R}=21\end{array}$ & $\begin{array}{l}\mathrm{K}-21= \\
35 \% \\
\mathrm{M}-14= \\
35 \% \\
\mathrm{R}=35\end{array}$ & 3,51 \\
\hline 10 (IV) & $\begin{array}{l}\mathrm{K}-4= \\
6,6 \% \\
\mathrm{M}-4= \\
10 \% \\
\mathrm{R}=8\end{array}$ & $\begin{array}{l}\mathrm{K}-3= \\
5 \% \\
\mathrm{M}-4= \\
10 \% \\
\mathrm{R}=7\end{array}$ & $\begin{array}{l}\mathrm{K}-18= \\
30 \% \\
\mathrm{M}-15= \\
37,5 \% \\
\mathrm{R}=33\end{array}$ & $\begin{array}{l}\mathrm{K}-16= \\
26 \% \\
\mathrm{M}-7= \\
17,5 \% \\
\mathrm{R}=23\end{array}$ & $\begin{array}{l}\mathrm{K}-19= \\
31,6 \% \\
\mathrm{M}-10= \\
25 \% \\
\mathrm{R}=29\end{array}$ & 3,58 \\
\hline 11 (IV) & $\begin{array}{l}\mathrm{K}-4= \\
6,6 \% \\
\mathrm{M}-4= \\
10 \% \\
\mathrm{R}=8\end{array}$ & $\begin{array}{l}\mathrm{K}-8= \\
13,3 \% \\
\mathrm{M}-5= \\
12,5 \% \\
\mathrm{R}=13\end{array}$ & $\begin{array}{l}\mathrm{K}-27= \\
45 \% \\
\mathrm{M}-14= \\
35 \% \\
\mathrm{R}=41\end{array}$ & $\begin{array}{l}\mathrm{K}-9= \\
15 \% \\
\mathrm{M}-7= \\
17,5 \% \\
\mathrm{R}=16\end{array}$ & $\begin{array}{l}\mathrm{K}-12= \\
20 \% \\
\mathrm{M}-10= \\
25 \% \\
\mathrm{R}=22\end{array}$ & 3,31 \\
\hline $12(\mathrm{~V})$ & $\begin{array}{l}\mathrm{K}-17= \\
28,3 \% \\
\mathrm{M}-14= \\
35 \% \\
\mathrm{R}=31\end{array}$ & $\begin{array}{l}\mathrm{K}-17= \\
28,3 \% \\
\mathrm{M}-7= \\
17,5 \% \\
\mathrm{R}=24\end{array}$ & $\begin{array}{l}\mathrm{K}-9= \\
15 \% \\
\mathrm{M}-7= \\
17,5 \% \\
\mathrm{R}=16\end{array}$ & $\begin{array}{l}\mathrm{K}-6= \\
10 \% \\
\mathrm{M}-2= \\
5 \% \\
\mathrm{R}=8\end{array}$ & $\begin{array}{l}\mathrm{K}-11= \\
18,3 \% \\
\mathrm{M}-10= \\
25 \% \\
\mathrm{R}=21\end{array}$ & 3,36 \\
\hline $13(\mathrm{~V})$ & $\begin{array}{l}\mathrm{K}-10= \\
16,6 \% \\
M-8= \\
20 \% \\
\mathrm{R}=18\end{array}$ & $\begin{array}{l}\mathrm{K}-12= \\
20 \% \\
\mathrm{M}-3= \\
7,5 \% \\
\mathrm{R}=15\end{array}$ & $\begin{array}{l}\mathrm{K}-22= \\
36,6 \% \\
\mathrm{M}-14= \\
35 \% \\
\mathrm{R}=36\end{array}$ & $\begin{array}{l}\mathrm{K}-5= \\
8,3 \% \\
\mathrm{M}-6= \\
15 \% \\
\mathrm{R}=11\end{array}$ & $\begin{array}{l}\mathrm{K}-11= \\
18,3 \% \\
\mathrm{M}-9= \\
22,5 \% \\
\mathrm{R}=20\end{array}$ & 3,00 \\
\hline $14(\mathrm{VI})$ & $\begin{array}{l}\mathrm{K}-35= \\
58,3 \% \\
\mathrm{M}-21= \\
52,5 \% \\
\mathrm{R}=56\end{array}$ & $\begin{array}{l}\mathrm{K}-9= \\
15 \% \\
M-7= \\
17,5 \% \\
\mathrm{R}=16\end{array}$ & $\begin{array}{l}\mathrm{K}-12= \\
20 \% \\
\mathrm{M}-7= \\
17,5 \% \\
\mathrm{R}=19\end{array}$ & $\begin{array}{l}\mathrm{K}-2= \\
3,3 \% \\
\mathrm{M}-2= \\
5 \% \\
\mathrm{R}=4\end{array}$ & $\begin{array}{l}\mathrm{K}-2= \\
3,3 \% \\
\mathrm{M}-3= \\
7,5 \% \\
\mathrm{R}=5\end{array}$ & 1,86 \\
\hline
\end{tabular}


Tab. 2. Stosunek młodzieży do wybranych norm moralnych (cd.)

\begin{tabular}{|c|c|c|c|c|c|c|}
\hline $\begin{array}{l}\text { Pytanie/ } \\
\text { Przyka- } \\
\text { zanie }\end{array}$ & $\begin{array}{l}\text { Zdecydo- } \\
\text { wanie się } \\
\text { zgadzam }\end{array}$ & $\begin{array}{l}\text { Raczej się } \\
\text { zgadzam }\end{array}$ & $\begin{array}{l}\text { Trudno } \\
\text { powie- } \\
\text { dzieć }\end{array}$ & $\begin{array}{l}\text { Raczej się } \\
\text { nie zga- } \\
\text { dzam }\end{array}$ & $\begin{array}{l}\text { Zdecydowa- } \\
\text { nie się nie } \\
\text { zgadzam }\end{array}$ & Średnia \\
\hline $15(\mathrm{VI})$ & $\begin{array}{l}K-27= \\
45 \% \\
M-17= \\
42,5 \% \\
R=44\end{array}$ & $\begin{array}{l}\mathrm{K}-13= \\
21,6 \% \\
\mathrm{M}-7= \\
17,5 \% \\
\mathrm{R}=20\end{array}$ & $\begin{array}{l}\mathrm{K}-13= \\
21,6 \% \\
\mathrm{M}-10= \\
25 \% \\
\mathrm{R}=23\end{array}$ & $\begin{array}{l}\mathrm{K}-3= \\
5 \% \\
\mathrm{M}-3= \\
7,5 \% \\
\mathrm{R}=6\end{array}$ & $\begin{array}{l}\mathrm{K}-4= \\
6,6 \% \\
M-3= \\
7,5 \% \\
\mathrm{R}=7\end{array}$ & 2,52 \\
\hline 16 (VII) & $\begin{array}{l}\mathrm{K}-2= \\
3,3 \% \\
\mathrm{M}-0 \\
\mathrm{R}=2\end{array}$ & $\begin{array}{l}\mathrm{K}-1= \\
1,6 \% \\
\mathrm{M}-1= \\
2,5 \% \\
\mathrm{R}=2\end{array}$ & $\begin{array}{l}\mathrm{K}-1= \\
1,6 \% \\
M-3= \\
7,5 \% \\
\mathrm{R}=4\end{array}$ & $\begin{array}{l}\mathrm{K}-17= \\
28,3 \% \\
\mathrm{M}-8= \\
20 \% \\
\mathrm{R}=25\end{array}$ & $\begin{array}{l}\mathrm{K}-39= \\
65 \% \\
M-28= \\
70 \% \\
\mathrm{R}=67\end{array}$ & 4,53 \\
\hline 17 (VII) & $\begin{array}{l}\mathrm{K}-10= \\
16,6 \% \\
M-11= \\
27,5 \% \\
\mathrm{R}=21\end{array}$ & $\begin{array}{l}\mathrm{K}-16= \\
26,6 \% \\
M-10= \\
25 \% \\
\mathrm{R}=26\end{array}$ & $\begin{array}{l}\mathrm{K}-13= \\
21,6 \% \\
\mathrm{M}-12= \\
30 \% \\
\mathrm{R}=25\end{array}$ & $\begin{array}{l}\mathrm{K}-12= \\
20 \% \\
\mathrm{M}-4= \\
10 \% \\
\mathrm{R}=16\end{array}$ & $\begin{array}{l}\mathrm{K}-9= \\
15 \% \\
\mathrm{M}-3= \\
7,5 \% \\
\mathrm{R}=12\end{array}$ & 2,72 \\
\hline 18 (VIII) & $\begin{array}{l}\mathrm{K}-4= \\
6,6 \% \\
M-4= \\
10 \% \\
\mathrm{R}=8\end{array}$ & $\begin{array}{l}\mathrm{K}-7= \\
11,6 \% \\
M-7= \\
17,5 \% \\
\mathrm{R}=14\end{array}$ & $\begin{array}{l}\mathrm{K}-24= \\
40 \% \\
\mathrm{M}-9= \\
22,5 \% \\
\mathrm{R}=33\end{array}$ & $\begin{array}{l}\mathrm{K}-14= \\
23,3 \% \\
M-8= \\
20 \% \\
\mathrm{R}=22\end{array}$ & $\begin{array}{l}\mathrm{K}-11= \\
18,3 \% \\
\mathrm{M}-12= \\
30 \% \\
\mathrm{R}=23\end{array}$ & 3,38 \\
\hline 19 (VIII) & $\begin{array}{l}\mathrm{K}-3= \\
5 \% \\
\mathrm{M}-1 \\
=2,5 \% \\
\mathrm{R}=4\end{array}$ & $\begin{array}{l}\mathrm{K}-0 \\
\mathrm{M}-1= \\
2,5 \% \\
\mathrm{R}=1\end{array}$ & $\begin{array}{l}\mathrm{K}-3= \\
5 \% \\
\mathrm{M}-2= \\
5 \% \\
\mathrm{R}=5\end{array}$ & $\begin{array}{l}\mathrm{K}-4= \\
6,6 \% \\
M-9= \\
22,5 \% \\
\mathrm{R}=13\end{array}$ & $\begin{array}{l}K-50= \\
83,3 \% \\
M-27= \\
67,5 \% \\
R=77\end{array}$ & 4,58 \\
\hline 20 (IX) & $\begin{array}{l}\mathrm{K}-16= \\
26,6 \% \\
M-12= \\
30 \% \\
\mathrm{R}=28\end{array}$ & $\begin{array}{l}\mathrm{K}-10= \\
16,6 \% \\
M-6= \\
15 \% \\
\mathrm{R}=16\end{array}$ & $\begin{array}{l}\mathrm{K}-21= \\
35 \% \\
\mathrm{M}-11= \\
27,5 \% \\
\mathrm{R}=32\end{array}$ & $\begin{array}{l}K-3= \\
5 \% \\
M-7= \\
17,5 \% \\
R=10\end{array}$ & $\begin{array}{l}\mathrm{K}-10= \\
16,6 \% \\
M-4= \\
10 \% \\
\mathrm{R}=14\end{array}$ & 2,66 \\
\hline 21 (IX) & $\begin{array}{l}K-9= \\
15 \% \\
M-10= \\
25 \% \\
R=19\end{array}$ & $\begin{array}{l}\mathrm{K}-9= \\
15 \% \\
M-9= \\
22,5 \% \\
\mathrm{R}=18\end{array}$ & $\begin{array}{l}\mathrm{K}-21= \\
35 \% \\
\mathrm{M}-12= \\
30 \% \\
\mathrm{R}=33\end{array}$ & $\begin{array}{l}\mathrm{K}-9= \\
15 \% \\
\mathrm{M}-4= \\
10 \% \\
\mathrm{R}=13\end{array}$ & $\begin{array}{l}K-12= \\
20 \% \\
M-5= \\
12,5 \% \\
R=17\end{array}$ & 2,91 \\
\hline
\end{tabular}


Tab. 2. Stosunek młodzieży do wybranych norm moralnych (cd.)

\begin{tabular}{|l|l|l|l|l|l|l|}
\hline $\begin{array}{l}\text { Pytanie/ } \\
\text { Przyka- } \\
\text { zanie }\end{array}$ & $\begin{array}{l}\text { Zdecydo- } \\
\text { wanie się } \\
\text { zgadzam }\end{array}$ & $\begin{array}{l}\text { Raczej się } \\
\text { zgadzam }\end{array}$ & $\begin{array}{l}\text { Trudno } \\
\text { powie- } \\
\text { dzieć }\end{array}$ & $\begin{array}{l}\text { Raczej się } \\
\text { nie zga- } \\
\text { dzam }\end{array}$ & $\begin{array}{l}\text { Zdecydowa- } \\
\text { nie się nie } \\
\text { zgadzam }\end{array}$ & Srednia \\
\hline $22(\mathrm{X})$ & $\mathrm{K}-3=$ & $\mathrm{K}-1=$ & $\mathrm{K}-6=$ & $\mathrm{K}-13=$ & $\mathrm{K}-37=$ & 4,10 \\
& $5 \%$ & $1,6 \%$ & $10 \%$ & $21,6 \%$ & $61,6 \%$ \\
& $\mathrm{M}-5=$ & $\mathrm{M}-2=$ & $\mathrm{M}-8=$ & $\mathrm{M}-8=$ & $\mathrm{M}-17=$ & \\
& $12,5 \%$ & $5 \%$ & $20 \%$ & $20 \%$ & $42,5 \%$ & \\
& $\mathrm{R}=8$ & $\mathrm{R}=3$ & $\mathrm{R}=14$ & $\mathrm{R}=21$ & $\mathrm{R}=54$ & \\
\hline $23(\mathrm{X})$ & $\mathrm{K}-5=$ & $\mathrm{K}-2=$ & $\mathrm{K}-8=$ & $\mathrm{K}-12=$ & $\mathrm{K}-33=$ & 3,87 \\
& $8,3 \%$ & $3,3 \%$ & $13,3 \%$ & $20 \%$ & $55 \%$ & \\
& $\mathrm{M}-5=$ & $\mathrm{M}-5=$ & $\mathrm{M}-10=$ & $\mathrm{M}-4=$ & $\mathrm{M}-16=$ & \\
& $12,5 \%$ & $12,5 \%$ & $25 \%$ & $10 \%$ & $40 \%$ & $\mathrm{R}=49$ \\
& $\mathrm{R}=10$ & $\mathrm{R}=7$ & $\mathrm{R}=18$ & $\mathrm{R}=16$ & $\mathrm{R}=16$ & \\
\hline
\end{tabular}

* $\mathrm{K}$ - uczennice, $\mathrm{M}$ - uczniowie

Źródło: opracowanie własne.

\section{Omówienie wyników badań}

Dokonując przeglądu wyników badań dotyczących stosunku młodzieży do wybranych norm moralnych Dekalogu, gdzie 5 oznacza wartość największą (zdecydowanie zgadzam się), a 1 wartość najmniejszą (zdecydowanie nie zgadzam się), możemy zauważyć następujące prawidłowości:

- w sferze stosunku deklarowanego najwyższą średnią uzyskały przykazania IV (Czcij ojca i matkę swoją), V (Nie zabijaj) i VII (Nie kradnij) ponad $90 \%$ dziewcząt zdecydowanie zgadza się z treścią tych przykazań;

- najniższą średnią w sferze stosunku deklarowanego uzyskało przykazanie II (Nie będziesz brał imienia Pana Boga swego nadaremno);

- w sferze stosunku urzeczywistnianego największą średnią uzyskały przykazania VIII (Nie mów fałszywego świadectwa przeciw bliźniemu swemu), VII (Nie kradnij) i X (Ani żadnej rzeczy, która jego jest) - 83\% dziewcząt i $67 \%$ chłopców zdecydowanie nie zgadza się z tym, że umieszczenie w Internecie dla zabawy filmu stawiającego koleżankę lub kolegę w złym świetle jest dopuszczalne; 70\% chłopców i 65\% dziewcząt zdecydowanie nie zgadza się ze stwierdzeniem: „Jeśli przypuszcza się, że rodzice mogą nie dać pieniędzy na kosmetyki lub na doładowanie telefonu komórkowego - 
można je wziąć (zabrać) z portfela rodziców po kryjomu". 61\% dziewcząt zdecydowanie nie zgadza się z tym, że dobieranie sobie przyjaciół ze względu na to, że są bogaci, nie jest czymś złym;

- w sferze stosunku urzeczywistnianego najniższą średnią uzyskały przykazania VI (Nie cudzołóż), IX (Nie pożądaj żony bliźniego swego), I (Nie będziesz miał bogów cudzych przede mną) oraz II (Nie będziesz brał imienia Pana Boga swego nadaremno). Prawie $60 \%$ dziewcząt i 52\% chłopców zdecydowanie zgadza się na współżycie seksualne przed ślubem, jeśli narzeczeni uważają, że się kochają; 45\% dziewcząt i 42\% chłopców zdecydowanie zgadza się ze stwierdzeniem: „Masturbacja nie jest czymś złym, bo jest to normalny etap rozwoju w życiu seksualnym człowieka”. Prawie 52\% dziewcząt i 42\% chłopców zdecydowanie zgadza się z tym, że powieszenie we własnym pokoju plakatu swojego idola (piosenkarza, aktora, piłkarza itp.) zamiast krzyża nie jest czymś złym.

\section{Podsumowanie}

Wydaje się, że po przeanalizowaniu badań można „pokusić się” o postawienie pewnych tez. Po pierwsze istnieją rozbieżności między "teorią" i ,praktyką”, to znaczy stosunkiem deklarowanym wobec „litery Dekalogu” i stosunkiem urzeczywistnianym wobec „ducha Dekalogu” przez młodzież. Należy podkreślić, że na pytania zawarte $\mathrm{w}$ ankiecie odpowiadała młodzież uczęszczająca na lekcje religii wyznania rzymskokatolickiego. Generalnie stosunek deklarowany jest wyższy od stosunku urzeczywistnianego w praktyce. Może to być powiązane z deficytami edukacji religijnej, oderwaniem nauczanych treści od codziennego życia. Może też być wynikiem braku interioryzacji i wewnętrznej akceptacji norm moralnych przez młodych.

Po wtóre wydaje się, że wśród młodzieży poszerza się sfera permisywności. W obecnym społeczeństwie (post)modernistycznym chętnie dokonuje się dekonstrukcji wszystkich instancji, które nakazują jakieś działania lub czegoś zakazują. Nie ma prawd (wartości, norm) obiektywnych, które obowiązują zawsze i wszędzie oraz odnoszą się do każdego człowieka. Zobowiązujące są tylko te prawdy, które są wynikiem wolnego wyboru, dokonywanego przez działający podmiot, mają odniesienie do danego momentu w życiu.

Procesy te utraciwszy wsparcie państwowej laicyzacji odnalazły swoje współczesne wzmocnienie w wolnym rynku idei i światopoglądów, przenikających 
różne dziedziny ludzkiej aktywności, penetrując najgłębsze obszary emocji i racjonalnych wyborów. „Heretycki imperatyw wyboru” zdaje się przekształcać w wartość autoteliczną, odmawiając religijnej tradycji prawa do legitymizowania ładu społecznego świata i kierunku jego rozwoju. W lansowanym modelu indywidualnego sukcesu tradycyjnie pojmowana moralność traktowana jest jak nieużyteczny balast i pamiątka historii eksponowana w muzeum przeszłości ${ }^{14}$.

Po trzecie, niezależnie od zmian idących w kierunku permisywizmu i relatywizmu moralnego, należy ogólnie podkreślić, że autonomizację postaw i zachowań moralnych młodzieży oraz uniezależnianie się moralności od religii widać szczególnie wyraźnie w odniesieniu do norm życia płciowego, które w sposób najbardziej wyraźny wiążą się z religią. Wiele innych norm (np. szacunek do rodziców, poszanowanie cudzej własności itd.) może nie łączyć się bezpośrednio z religią, wypływać z przekonań etycznych, wychowania rodzinnego. Wielu młodych ludzi normy dotyczące seksualności akceptuje warunkowo, częściowo kwestionuje, a niektóre zdecydowanie odrzuca. Rozdźwięk pomiędzy moralnym nauczaniem Kościoła katolickiego oraz poglądami i zachowaniami młodzieży (a zwłaszcza dziewcząt) zaznacza się w sprawach związanych z życiem seksualnym, normami moralnymi regulującymi pożycie małżeńskie i z nierozerwalnością małżeństwa. Może to być powiązane $\mathrm{z}$ nieodpowiednim wychowaniem seksualnym $\mathrm{w}$ rodzinie i w szkole, wcześniejszym dojrzewaniem płciowym dziewcząt, modą na wczesną inicjację seksualną wśród gimnazjalistów, coraz częstszym zjawiskiem rodzin w sytuacjach kryzysu.

W Polsce coraz wyraźniej uwidaczniają się symptomy ,sekularyzacji moralności", która wyraża się w tym, że Polacy w coraz mniejszym stopniu odczuwają potrzebę religijnego uzasadniania własnych zasad moralnych i w wielu kwestiach deklarują poglądy moralne niezgodne $\mathrm{z}$ wyznawaną przez siebie religią. Nierzadko dotyczy to osób określających się jako wierzące (a nawet głęboko wierzące) oraz regularnie praktykujące religijnie. Przypisywanie sobie wysokiego poziomu religijności, a - tym bardziej - ponadprzeciętnej moralności bardzo często wiąże się z jednoczesnym przyzwoleniem na stosowanie środków antykoncepcyjnych, seks przedmałżeński czy rozwody. Niemniej jednak zasady moralne proponowane przez Kościół katolicki, choć przez większość formalnie ochrzczonych katolików uznawane za często niezbyt dobrze przystające do dzisiejszej rzeczywistości i wyma-

${ }^{14}$ Wojciech Świątkiewicz, Tradycja i wybór. Socjologiczne studium religijności na Górnym Ślasku (Katowice-Wrocław: Instytut Górnośląski, 1997), 157-158. 
gające uzupełnienia, w wielu kwestiach znajdują uznanie i akceptację również wśród osób określających się jako niereligijne lub niewierzące.

Wychowanie moralne, wychowanie do wartości staje się wyzwaniem dla edukacji i wychowania człowieka rozumianego wielowymiarowo. Okazuje się, że ta sfera działalności pedagogicznej jest w wielu krajach Europy mających chrześcijańskie korzenie w stanie kryzysu i chaosu. Młodzieży często brakuje świadectwa życia zgodnego z Dekalogiem w domu rodzinnym, w środowisku szkolnym i otaczającym ją kontekście społecznym. Ponadto daje się zauważyć promowanie postaw relatywistycznych, deprecjonowanie roli religii w życiu człowieka, przyzwalanie na sytuacje destruktywnie wpływające na życie młodzieży. Szczególnie niszczące dla młodego człowieka i społeczeństwa jest „osadzenie na tronie Króla Seks”'15. Skutkuje to tym, iż generalnie rzecz ujmując - daje się zauważyć odchodzenie od moralności bezwarunkowego zakazu do moralności indywidualnego osądu. W warunkach ponowoczesności każdemu wydaje się, że ma prawo do eksperymentowania w swoim życiu, także i w dziedzinie wyborów moralnych. Czasy ponowoczesne wiążą się z konstruowaniem własnej tożsamości osobowej i społecznej. Taka osobowość nie jest dana „raz na zawsze”, odgórnie, lecz jest ustawicznie tworzona. W działaniach ludzi współczesnych trudno dostrzec bezpośredni związek z wartościami i normami bezwzględnymi. Taka postawa może być bardzo niebezpieczna, jak bowiem pisał Fiodor Dostojewski w Braciach Karamazow: ,jeśli Boga nie ma, wszystko jest dozwolone".

Religia i system norm moralnych mogą stanowić o przyszłości życia społecznego, o jego jakości. Z katolickiego punktu widzenia, uznającego zakorzenienie wartości oraz norm moralnych w naturze człowieka stworzonego na obraz i podobieństwo Boga, wydaje się właściwe nawoływanie do formowania „człowieka sumienia”, odczytującego poprawnie odwieczną prawdę Bożą (głos Boga) w swoim wnętrzu; prowadzenie procesu pedagogicznego w taki sposób, aby wartości i normy moralne były jasno, wyraźnie przedstawiane (i ukazywane w konkretnych sytuacjach życia współczesnej młodzieży) oraz w duchu wolności interioryzowane i akceptowane. Mając zaś na uwadze rozdźwięk między moralnym nauczaniem Kościoła rzymskokatolickiego a postawami związanymi z życiem płciowym, szczególnie ważna dla wychowania młodzieży wydaje się sprawa promowania odpowiedniego wychowania seksualnego w rodzinie i w szkole.

15 Por. Józef Augustyn, Wychowanie seksualne w rodzinie $i$ w szkole (Kraków: Wydawnictwo M, 1997), 36. 


\section{The Attitude of Junior High School Students towards Certain Moral Norms Contained in the Ten Commandments (Summary)}

Some axiological and normative issues are now of high interest of the representatives of various branches of science, including educators and sociologists. Education for values is an integral part of humans' education - and it becomes primarily the domain of religious education. The Decalogue (Greek: Ten words, "ten commandments"), as an expression of the fundamental duties of a man towards the God and towards one's neighbour (morals), reveals serious commitments in its essential content. They are by their nature immutable and apply to believers always and everywhere.

The problem of the research is expressed in the question: what is the attitude of young people towards the moral norms contained in the Ten Commandments? The article presents the declared (theoretical) attitude of young people towards the moral norms contained in the Ten Commandments, and towards their real attitudes to life based on moral standards referring to the ten commandments of God. They are therefore the attitudes expressing a more practical dimension - implementation of norms revealed by God in a daily life.

Key words: the Ten Commandments; religious socialization; religious education; moral education; norms.

\section{Stosunek młodzieży gimnazjalnej do wybranych norm moralnych zawartych w Dekalogu (Streszczenie)}

Kwestie aksjologiczne i normatywne znajdują się obecnie w centrum zainteresowań przedstawicieli różnych gałęzi nauki, także pedagogów czy socjologów. Wychowanie do wartości jest częścią integralnego wychowania człowieka - staje się przede wszystkim domeną wychowania religijnego. Dekalog (gr. 'dziesięć słów', 'dziesięć przykazań Bożych'), będąc wyrazem podstawowych powinności człowieka względem Boga i wobec bliźniego (norm moralnych), objawia w swojej istotnej treści poważne zobowiązania. Są one ze swojej natury niezmienne i obowiązują wierzących zawsze i wszędzie. Problem, który stał się motywem podjęcia badań, wyraża się w pytaniu: jaki jest stosunek młodzieży do norm moralnych zawartych w Dekalogu? Artykuł przedstawia deklarowany (teoretyczny) stosunek młodzieży 
do norm moralnych zawartych w Dekalogu oraz stosunek młodzieży wobec postaw życiowych stanowiących rozwinięcie norm moralnych na bazie dziesięciu Bożych przykazań. Jest to więc stosunek wyrażający bardziej praktyczny wymiar - realizowanie w codziennym życiu norm objawionych przez Boga.

Słowa kluczowe: dekalog; socjalizacja religijna; wychowanie religijne; wychowanie moralne; normy.

\section{Bibliografia}

Augustyn, Józef. Wychowanie seksualne w rodzinie $i$ w szkole. Kraków: Wydawnictwo M, 1997.

Maty Stownik Teologiczny, red. Karl Rahner, Herbert Vorgrimler, thum. Tadeusz Mieszkowski, Paweł Pachciarek. Warszawa: Instytut Wydawniczy PAX, 1996. Rusecki, Marian. „Religia IV: aspekt teologiczny”. W: Encyklopedia Katolicka, t. XVI, red. Edward Gigilewicz i in., 1405-1415. Lublin: TN KUL, 2012.

Katechizm Kościoła katolickiego. Poznań: Pallottinum, 1984.

Libiszowska-Żółtkowska, Maria, Janusz Mariański. Leksykon socjologii religii.

Warszawa: Verbinum, 2004.

Mielicka, Halina. „Wartości ekonomiczne a systemy normatywne”. W: Badania Naukowe, z. 5, red. Bożydar J. L. Kaczmarek, 120-132. Kielce: Wyższa Szkoła Ubezpieczeń Społecznych w Kielcach, 2001.

Ossowska, Maria. „Czy moralność zależy od religii?” Nowa Szkoła 6 (1958): 2-6.

Religijność a zasady moralne. Warszawa: CBOS, 2014.

Rogowski, Cyprian. Pedagogika religii. Toruń: Wydawnictwo Adam Marszałek, 2011.

Salij, Jacek. Dekalog. Poznań: Księgarnia Św. Wojciecha, 1990.

Świątkiewicz, Wojciech. Tradycja i wybór. Socjologiczne studium religijności na Górnym Ślasku. Katowice-Wrocław: Instytut Górnośląski, 1997. 